\title{
POBREZA POLÍTICA E MARGINALIDADE
}

Laura Frade*

\section{Introdução}

O objetivo desse trabalho é analisar a marginalidade como fenômeno decorrente da pobreza política. Não apenas como um esforço teórico vazio e racionalizante e sim fruto da necessidade de obter no conhecimento ferramenta real de libertação para grupos de seres humanos que clamam pela superação de um estado escravizante e apequenador. Utilizando um caso concreto - o Centro de Progressão Penitenciária de Brasília - nos propomos a debater a eficiência das políticas sociais no Distrito Federal, voltada, nesse caso, à reintegração dos marginais à sociedade local.

Registre-se que a marginalidade em pauta é aquela decorrente do descumprimento da lei. Regra criada pelo Legislativo Federal, que constrói o limite do transbordamento e a entrada no universo da margem - daí a marginalidade.

Tratando-se de fenômeno de ampla complexidade, onde os ensinamentos de Edgar Morin enfatizam a importância de nos abrirmos para a captação da realidade e não seu enclausuramento em um método vazio, o procedimento adotado para a tarefa proposta estará centrado em:

1. clareamento dos conceitos de pobreza política e marginalidade;

2. contextualização sócio-histórica, o que envolve questões do âmbito da Filosofia (o Homem nasce mau? Sob a ótica da abordagem de Rousseau ao tratar da origem da desigualdade entre os homens), da Antropologia (estampagens básicas na cultura ocidental registradas por Campbell, e a "lógica do destino humano", segundo a visão de Wright), da Biologia (a complexidade da mente e as alterações que podem marginalizar o indivíduo) e da Sociologia e, por fim,

3. Análise do trabalho desenvolvido pelo CPP-DF na tarefa de reintegrar indivíduos marginais à família e à sociedade.

Certamente não esgotaremos tarefa dessa monta em tão poucas páginas - até porque o fenômeno histórico-estrutural da sociedade parece manter em pauta as desigualdades,

\footnotetext{
* Professora do Centro Universitário Euro-Americano (UNIEURO).
} 
inclusive como ferramenta de sua própria mudança -, mas, iniciar o debate com a instalação de alguns pilares norteadores, parece urgente e necessário.

\section{Pobreza Política e Marginalidade}

A pobreza política é a faceta mais dura da expressão histórica da pobreza humana, produzida em sociedade ${ }^{1}$. É aquela que, para mais além de retirar o Homem do universo do TER, o exclui do espaço do SER. Obviamente que as carências materiais se nos apresentam de forma mais direta e objetiva, mas a falta material, em si, não implica a desigualdade, desde que seja a mesma para todos. O que se coloca de forma menos perceptível às análises superficiais e que se evidencia diante de uma abordagem complexa é que, dada as desigualdades econômicas, os agentes históricos que disputam poder, prestígio, oportunidades, vantagens e lideranças, passam a usar essas desigualdades a seu favor ${ }^{2}$, muitas vezes se valendo do poder que possuem para construir as regras, sob a forma de lei.

Demo afirma, em obra de $1998^{3}$, que há um vazio teórico no tocante à questão da marginalidade, da exclusão social. Seu texto está voltado a fazer uma análise dos autores que integram as duas grandes correntes teóricas sob as quais o estudo do tema é feito hoje: a mais voltada para os aspectos econômicos, resultantes das contradições do modo de produção capitalista, e a outra, de inspiração culturalista, que dá ênfase aos traços psicossociais implicados. Criticando os autores, constrói a defesa de sua tese de vazio teórico e defende a retomada do tema sob uma abordagem mais ampla, política e cidadã.

$\mathrm{Na}$ tentativa de reproduzirmos o apanhado conceitual que o autor produz a respeito do fenômeno da exclusão produzido pela pobreza, procedemos ao levantamento dos conceitos referidos por diferentes teóricos que pode ser expresso no quadro abaixo:

\begin{tabular}{|c|l|}
\hline Autor & \multicolumn{1}{|c|}{ Definição } \\
\hline PAUGAM, S. & $\begin{array}{l}\text { Exclusão seria noção familiar nos últimos anos, destinada a retratar a } \\
\text { angústia de numerosos segmentos da população “inquietos diante do } \\
\text { risco de se ver um dia presos na espiral da precariedade", acompanhando }\end{array}$ \\
\hline
\end{tabular}

\footnotetext{
${ }^{1}$ DEMO, Pedro. Pobreza Politica (Pobreza Humana). site: $\underline{\text { http://pedrodemo.sites.uol.com.br }}$

${ }^{2}$ DEMO, Pedro. Pobreza Politica. Campinas: Editora Autores Associados, 1996

${ }^{3}$ DEMO, Pedro (1998). "Exclusão Social - categorias novas para velhas realidades" in SER SOCIAL Exclusão Social e Situações de Risco", Revista do Programa de Pós-Graduação em Política Social do Departamento de Serviço Social da Universidade de Brasília, Número 3, julho a dezembro de 1998. P. 12 - 55
} 


\begin{tabular}{|c|c|}
\hline & $\begin{array}{l}\text { "o sentimento quase generalizado de uma degradação da coesão social". } \\
\text { Reconhece, porém, que se trata de um termo ainda equívoco, abarcando } \\
\text { preocupações como propriedade do emprego, ausência de qualificação, } \\
\text { desocupação, incerteza do futuro, privação material combinada com } \\
\text { degradação moral e de socialização, desilusão do progresso, } \\
\text { incapacidade de reagir. Refere três patamares de pobreza: integrada, } \\
\text { marginal e desqualificada" (in DEMO, } 1998, \text { p. } 10 \text { e 20) }\end{array}$ \\
\hline $\begin{array}{l}\text { SCHNAPPER, } \\
\text { D. }\end{array}$ & $\begin{array}{l}\text { "Reforça o distanciamento frente à explicação marxista alegando que o } \\
\text { "paradigma da exclusão" tornou-se dominante após o paradigma da luta } \\
\text { de classes e das desigualdades. O sistema capitalista conseguira, apesar } \\
\text { de suas pretensões anti-sociais notórias, contribuir para a integração } \\
\text { social...a decomposição de sua coesão social agrava a questão da } \\
\text { sobrevivência. Começa a emergir um processo de "desfiliação"" (in } \\
\text { DEMO, p. 13) }\end{array}$ \\
\hline CASTEL, R. ${ }^{4}$ & $\begin{array}{l}\text { Um dos teóricos mais reconhecidos da exclusão social. "A Margem é } \\
\text { uma fronteira" (in CASTEL, "Os marginais na história" in Ser Social 3, } \\
\text { UnB, 1998) "Fala de "desenraizamento" como fenômeno fundamental no } \\
\text { começo do processo de exclusão". ..A exclusão não se esgota no } \\
\text { afastamento do mercado de trabalho, mas ganha significação tanto mais } \\
\text { drástica no processo de destruição de valores integrativos tradicionais, } \\
\text { atingindo os patamares da precariedade marcada pela não-pertença e } \\
\text { impotência"(in DEMO, p. 14). }\end{array}$ \\
\hline $\begin{array}{l}\text { ROSANVALLO } \\
\text { N,P. }\end{array}$ & $\begin{array}{l}\text { Considera os excluídos como "não-força" social . Sua análise enriquece } \\
\text { o lado da exclusão social para além da determinação econômica mas a } \\
\text { imagina como um fenômeno de simples justaposição. Refere a "auto- } \\
\text { exclusão", assistência. (in DEMO, p. 15) }\end{array}$ \\
\hline $\begin{array}{l}\text { WACQUANT, } \\
\text { L. }\end{array}$ & $\begin{array}{l}\text { Faz crítica ao termo "underclass" como parte de um sistema que recusa } \\
\text { reconhecer sua decadência social e que designa, mais que tudo, uma } \\
\text { coleção de comportamentos anti-sociais. A "concepção neo-ecológica" } \\
\text { toma força e surge a idéia de bairro como incubador da marginalidade. } \\
\text { Passa-se a acusar a vítima. O isolamento no bairro agrava a posição fraca } \\
\text { diante do mercado. Cria um contexto injusto de acusação moralista diz } \\
\text { este autor. (in DEMO, p. 16) }\end{array}$ \\
\hline FASSIN, D. & $\begin{array}{l}\text { "Se considerarmos as topologias simbólicas pelas quais as sociedades se } \\
\text { representam para si mesmas, é notável que, no decorrer do período } \\
\text { recente, o desenvolvimento da pobreza urbana deu lugar a três figuras } \\
\text { diferentes - exclusão na França, underclass nos Estados Unidos, } \\
\text { marginalidad na América Latina - que reproduz as três configurações do } \\
\text { espaço social - dentro/fora, alto/baixo, centro/periferia, respectivamente. } \\
\text { Cada disciplina põe seu acento próprio, quando fala da marginalidade: a } \\
\text { economia recorre ao mercado de trabalho, a psicologia aos distúrbios de } \\
\text { comportamento, e a sociologia, às condutas desviantes...As populações } \\
\text { descritas como marginais constituem de fato a maioria dos habitantes das }\end{array}$ \\
\hline
\end{tabular}

${ }^{4}$ CASTEL, R. (1998) "Os Marginais na História" in SER SOCIAL - Exclusão Social e Situações de Risco", Revista do Programa de Pós-Graduação em Política Social do Departamento de Serviço Social da Universidade de Brasília, Número 3, julho a dezembro de 1998. p. 55-67 


\begin{tabular}{|l|l|}
\hline & cidades. Ele foca a dimensão econômica como a mais relevante" \\
\hline PROCACCI, G. & $\begin{array}{l}\text { Aponta, como Demo, em um vazio teórico, ao reconhecer que “o } \\
\text { liberalismo teria interesse em incluir os pobres no mercado, preferindo } \\
\text { isto à caridade tradicional, embora sempre sob a ótica do mercado... A } \\
\text { origem histórica da desigualdade não natural seria uma economia mal } \\
\text { conduzida. Refere o horizonte dos direitos da cidadania. A exclusão é } \\
\text { essencialmente um processo pelo qual maiorias são afastadas dos acessos } \\
\text { integradores principais na sociedade, sobretudo no mercado de trabalho. } \\
\text { Embora desigualdade não possa explicar tudo, pela simples razão lógica } \\
\text { de que uma causa única nunca consegue tal façanha, em particular no } \\
\text { contexto social"(in Demo, p. 22-23) }\end{array}$ \\
\hline
\end{tabular}

Demo sustenta, a título de conclusão, que as novas propostas de análise sobre a marginalidade e a exclusão social nada acrescentam de original. Trata-se, apenas, de novos olhares sobre os mesmos velhos problemas. De novo, talvez, apenas o fato de que "os países desenvolvidos precisam engolir em seco que não souberam resolver a questão social, que imaginavam já coisa do Terceiro Mundo” (p. 24). Afirma que no capitalismo qualquer processo de inclusão social passa pelo mercado, só ganha profundidade ao peso da cidadania envolvida, que o combate à pobreza exige como primeiro ato não a assistência, mas a reinvenção da cidadania do excluído.

Talvez por isso Sawaia ${ }^{5}$ questione a respeito da "exclusão ou inclusão perversa?", não com o intuito de reduzir as ambigüidades sobre o conceito mas sim propondo, como Morin e Castel, que assumamos a tarefa de incluir tais ambigüidades em nossas percepções intelectuais e trabalhos práticos. Assumirmos a dialética exclusão/inclusão para introduzirmos a "ética e a subjetividade na análise sociológica da desigualdade, ampliando as interpretações"...(p.8). Abandonando o "descompromisso político com o sofrimento do outro" (p. 8)

Tal postura nos remete à busca da visualização do processo de construção do marginal, do excluído, do desviante. E se questões econômicas e culturais foram o objeto sobre o qual os teóricos já referidos se debruçaram, Foucault ${ }^{6}$ ressalta um aspecto que é fundamental não apenas para esse trabalho mas como base de reflexão geral: a construção do conceito legal da criminalidade, do delito - aquilo que a sociedade, o Estado, ao definirem como "anormal", acabam por construir a própria figura do excluído. É o

\footnotetext{
${ }^{5}$ SAWAIA, Bader. Org. (2002). As Artimanhas da Exclusão. 4. ed. Rio de Janeiro: Vozes.

${ }^{6}$ FOUCAULT, M. (2001). Os Anormais. São Paulo: Martins Fontes - Curso no Collège de France.
} 
legislador, o juiz e os médicos que definem o "indivíduo perigoso", o "marginal", o "desviante". Ele refere o processo histórico de mudanças desses conceitos e volta a nos apontar, uma vez mais, nosso envolvimento "escondido" na elaboração de nossas próprias mazelas. Critica os exames médicos, laudos, posições profissionais inconsistentes e infantis e nos convida a mergulhar nas profundezas dos constructus de controle dos indivíduos, no Poder e nas formas de dominação do Estado. Trataremos mais especificamente dessa questão quando da análise sociológica a ser desenvolvida na próxima etapa de nosso trabalho, que envolve a contextualização sócio-histórica da marginalidade, enquanto fenômeno decorrente da pobreza política.

$\mathrm{Na}$ mesma linha - a da construção do transgressor - Batista ${ }^{7}$ procede ao levantamento do histórico da influência da criminologia e do positivismo no sistema penal que enquadra o indivíduo em padrões pré-estabelecidos, criando a margem onde se situam os "de dentro" e os "de fora". Os excluídos, os marginais. Utiliza o espaço dos adolescentes criminalizados por drogas para defender a crítica da realidade social e do direito. A revisão dos valores voltados à criminalização óbvia por classes sociais baixas, balizada por questões étnicas e pré-conceitos históricos. Bastante semelhante ao que Coimbra ${ }^{8}$ desenvolve ao mostrar que a construção de situações de risco decorre do nosso sistema de valores e acaba por traçar a linha de fronteira - não real - entre os "bons" e os "maus". Crenças essas que envolvem ditos como "bandido não é gente" e "bandido bom é bandido morto". Como se fosse possível ao bandido qualquer ingerência no processo de construção da definição do "ser bandido".

Em um trabalho novo, que aborda a criminalidade na classe alta, Souza ${ }^{9}$ discorre a respeito do assassinato de um índio, por adolescentes, em Brasília. Busca levantar as representações que eles têm das leis e estabelecer uma relação com os modelos identificatórios presentes na rede social. Mais uma tentativa de compreensão da forma sob a qual se constrói o transgressor.

\footnotetext{
${ }^{7}$ BATISTA, Vera. “A Construção do Transgressor", p. 157-163.

${ }^{8}$ COIMBRA, Cecília. "Produzindo o Mito da 'guerra civil': naturalizando a violência”, p. 165-173

${ }^{9}$ SOUZA, Meriti. “A Experiência Transgressiva: leis e adolescentes”. In Pulsional Revista de Psicanálise, ano XIV, n. $147,52-65$.
} 
O que define a saída do "normal"? Qual a função de cada referência, de cada rede primária e secundária - na construção desta saída? O que se passa "lá fora" enquanto o indivíduo vive a exclusão?

Ninguém responde claramente às questões colocadas. O terreno do complexo possui mesmo esta característica de acumular perguntas e perguntas. Algo como no dizer de Rilke em suas Cartas a um jovem poeta: há um tempo das perguntas e um tempo das respostas. E no tempo das perguntas há que vivê-las intensamente, profundamente, nos entregando a elas com toda a força e coragem de nossas entranhas.

A leitura de todos esses teóricos, se bem contribui para uma visão mais amplificada e clara das inúmeras visões sobre margem, desvio e exclusão social, não resulta em um apaziguamento interno ou/e intelectual. Ao contrário, reacende na alma quase uma ira. Impõem a impotência dos que se percebem desejosos de mudança e incapazes da síntese necessária a tal. Introduz claramente a visão da pobreza política que desumaniza, idiotiza e embrutece. Sinaliza a complexidade crescente que Morin diagnostica na produção do conhecimento e talvez signifique o estágio do ingresso na desordem. Essa que desconstrói o objeto culturalmente pré-estabelecido para que retrate mais fielmente a realidade. Permanece, entretanto, a frase de Demo, ressoando ao fundo uma certa lucidez:

"A carência material é a casca externa da desigualdade social implicada e que encontra seu cerne na 'pobreza política' "(DEMO, 1998, p. 24).

Se a construção da marginalidade está fundada, como referem os autores analisados, sobre questões econômicas, culturais, políticas e filosóficas. Se a construção do transgressor é fruto da aplicação automática e impensada de valores internalizados e por vezes invisíveis a nós mesmos, o desafio da intervenção parece centrar-se em uma ética cidadã a ser recuperada, reconstruída, elaborada. A produção de um conhecimento capaz de ultrapassar a subserviência aos modelos e padrões sociais. Um desafio no qual a mudança real na sociedade seja precedida pela mudança pessoal do próprio buscador. Um ato de coragem para alterar valores pessoais, um mergulho no caos organizador. Uma quebra de paradigma. A reconstrução do próprio universo interno.

Seguindo a linha proposta e buscando mergulhar no caos que primeiro desconstrói, para só então recompor, em novas bases, é que passamos à segunda etapa desse trabalho, 
colhendo, junto a diferentes áreas, informações que possam auxiliar no cumprimento da tarefa proposta de analisar a marginalidade como fenômeno decorrente da pobreza política.

\section{Contextualização Sócio-Histórica da Marginalidade}

Buscamos, na análise complexa e na dialética histórico-estrutural, um modelo para a abordagem da marginalidade como fenômeno decorrente da pobreza política. Parece conveniente, como ensina Demo ${ }^{10}$, "contextuar a análise no espaço e no tempo, atribuindo à inserção social e histórica, condição explicativa, não apenas conotativa. É sempre possível dar conta melhor do fenômeno social, se sabemos como se originou historicamente, em que condições sociais ocorre." (DEMO, 2002, p. 25)

No âmbito das reflexões filosóficas, as análises a respeito da natureza do Homem variam do extremo de considerá-lo naturalmente mau - personificadas nas produções de Hobbes que propõem o Leviatã como forma de cerceamento dessa natureza original - até a visão, defendida por Rousseau, de que nascemos bons e nos pervertemos no âmbito social. A reflexão desse último autor merece, a nosso ver, ser melhor explicitada. Instado pela Academia de Dijon, a refletir sobre a questão: Qual a origem da desigualdade entre os homens - e registre-se que a marginalidade gera desiguais, na medida em que uns estão "dentro"e outros "fora", à margem, excluídos - Rousseau resolveu deixar Paris e o convívio dos demais para, em uma floresta, refletir a respeito de como seria o Homem, quando ainda não vivia em sociedade, locus da desigualdade. Diversamente dos filósofos, pede aos fatos a confirmação de seus raciocínios, parte do estudo do corpo humano, das raças e dos povos ao buscar desvendar a natureza do Homem e daí vem a extrair a figura do legendário "bom selvagem".

Ele afirma que o conhecimento do Homem é o mais importante de todos os conhecimentos. Entretanto, esclarece, a dificuldade é distinguir como ele deveria ser, ou seja, em seu estado de natureza original, do homem em que se transformou com a evolução ao longo do tempo, incorporando mudanças exteriores e o progresso natural da espécie.

Sua reflexão é norteada por uma visão de abundância, coincidente com a do autor moderno Robert Wrigth, que será comentada mais adiante. Para Rousseau "Há, pois, uma

\footnotetext{
${ }^{10}$ DEMO, Pedro. Solidariedade como efeito de poder. São Paulo: Cortez, 2002.
} 
bondade original da natureza humana: a evolução social corrompeu-a" 11 (ROUSSEAU, 2000, p. 9). Ele defende a aplicação da idéia de base de que há uma igualdade original inscrita no homem natural e que causas físicas produziram, pouco a pouco, as várias desigualdades que, segundo ele, são artificiais. Foi sobre essas bases, inclusive, que o autor fundamentou o Direito natural sobre dois pilares: o instinto de conservação, que prende o homem a si mesmo, e a piedade, que o prende a outrem. Na conclusão do prefácio de seu texto, refere: “1) A oposição entre os poderosos e os fracos só superficialmente explica a evolução das sociedades. Impõe-se procurar um fundamento natural primitivo. 2) Esse fundamento permite distinguir aquilo que na sociedade foi desejado pela natureza, isto é, por Deus, do que foi produzido pelo homem" (ROUSSEAU, 2000, p. 10).

Distingue, assim, duas espécies de desigualdade: a desigualdade natural ou física, e a desigualdade moral e política e busca estudar não a relação entre elas, mas como se deu a passagem da primeira à segunda. Para tal, assume como método a busca do estado de natureza, através do raciocínio, evitando incorrer no erro freqüente dos filósofos, que é atribuir aos selvagens sentimentos dos civilizados. E separa fatos, porque, para ele, a história é contrária à natureza, o que o leva a perguntar o que teria acontecido ao gênero humano caso fosse abandonado a si mesmo?

Para analisar o estado de natureza, objetivando determinar se nele reina a desigualdade, Rousseau descarta os dados de origem sobrenatural e a evolução biológica do homem e considera que no estado de natureza o homem se encontra constituído, anatomicamente, como hoje. Esse último aspecto nos parece merecer reavaliação e será objeto de análise específica, quando na seqüência tratarmos das questões biológicas relativas à natureza humana.

Entretanto, mantendo nosso enfoque no trabalho realizado pelo autor, que reputamos como excelente e importante para a compreensão de questões humanas cruciais, registre-se que, do ponto de vista físico, ele conclui que "Os animais, uma vez domesticados, degeneram. Os selvagens, de acordo com relatos de viajantes, possuem a vista, o ouvido e o olfato mais desenvolvidos do que nós. Todo ser vivo é, pois, pela sua natureza, fisicamente forte. “ (ROUSSEAU, 2000, p. 15).

\footnotetext{
${ }^{11}$ ROUSSEAU, Jean-Jacques.Discurso sobre a Origem e os Fundamentos da Desigualdade entre os Homens. In Coleção Os Pensadores, Rousseau, vol. II, São Paulo: Editora Nova Cultural, 2000.
} 
Relativamente ao aspecto psicológico, afirma que "a sociabilidade não está inscrita na natureza humana original. O homem não tem necessidade de outrem. Não sofre nem a dor nem a miséria, que o tornariam digno de piedade. O estado de natureza caracteriza-se pela suficiência do instinto, o estado de sociedade pela suficiência da razão" (ROUSSEAU, 2000, p. 16).

Com relação ao último aspecto que analisa, o homem moral, o autor assevera que o homem, em estado de natureza, não é bom nem mau, já que ignora tanto as virtudes como os vícios, criados pelo estado social, o que lhe proporcionaria, na origem, maior felicidade. O primeiro princípio da moral natural, conforme se posiciona, é o instinto de conservação de si mesmo, afirmando que o erro de Hobbes foi acreditar que para conservar a si próprio impunha-se a luta mortal com os outros ou a escravização. Rousseau afirma que a ausência da bondade não implica, necessariamente, na maldade, podendo-se conservar a si próprio sem prejudicar a outrem. Interessante a observação que fecha sua conclusão nesse ponto de suas elucubrações: "Ora, o homem primitivo não poderia ser mau, uma vez que não sabia o que era bom e mau" (ROUSSEAU, 2000, p. 17). Importante registro faz o autor, na medida em que nos recorda que os conceitos valorativos nascem no seio da sociedade e variam conforme a cultura, incluindo aí, suas leis e regras de conduta. Mas, vai além na abordagem da moral: afirma que o segundo princípio da moral natural é a piedade. E a coloca não no contexto da religiosidade, mas sim da natureza, pois utiliza o instinto maternal como referência, assegurando que é um movimento da natureza, anterior à reflexão. Por último, defende a idéia de que as paixões são mais violentas no estado de natureza e fecha sua análise com as seguintes conclusões:

“1. A desigualdade é quase mula no estado de natureza. Em nenhuma de suas formas possui grande realidade ou influência. 2. A maioria das desigualdades resulta, com efeito, do hábito e da educação e, conseqüentemente, da sociedade que exercita ou não as forças do corpo e as do espírito. 3. As desigualdades naturais, de início fracas e insignificantes, são multiplicadas pela sociedade que, de um lado, aumenta os desejos e, de outro, favorece a cultura. Desse modo, só se notou a beleza depois de inventada pelo amor mental, e também a servidão e a dominação decorrentes da força e da riqueza só vieram a existir quando os homens convieram entre si quanto à sua dependência mútua". (ROUSSEAU, 2000, p. 18). 
$\mathrm{Na}$ seqüência, o autor esclarece que ainda seria necessário mostrar que a perfectibilidade e as virtudes sociais se desenvolveram, que o homem se tornou sociável e mau. Que isso poderia não ter ocorrido e o homem ter permanecido em seu estado natural, mas como assim não de seu, indispensável compreender os estágios pelos quais passou a humanidade, no seu desenvolvimento, caracterizando-se, cada um deles, por um novo crescimento da desigualdade: 1. Compromissos mútuos nascem das necessidades impostas pelas estações, condições geográficas e demais, decorrentes do próprio estado de natureza; 2. A constituição da família, de uma primeira forma de propriedade (habitação) e comodidades ignoradas pelos antepassados plantam os germes dos males futuros: a estima e a consideração pública surgem, criando as primeiras desigualdades e os primeiros deveres de civilidade, figurando como as primeiras fontes de contendas e de vingança. Introduz-se a moralidade, impõem-se a necessidade de policiar os costumes e de punir contraventores aqui, o homem já pode ser considerado cruel; 3. A invenção da propriedade suscita, por um lado, a existência da primeira desigualdade - a que separa ricos e pobres - mas de outro lado, a formação das primeiras sociedades civis, baseadas em leis; 4. A criação dos magistrados é, para Rousseau o momento da construção da Segunda grande desigualdade: a dos poderosos e a dos fracos, e, por fim, 5. O último progresso da desigualdade está vinculado ao surgimento do despotismo, à mudança do poder legítimo em poder arbitrário.

Note-se, pois, que, na visão do filósofo, a desigualdade não é legítima do ponto de vista natural. O desaparecimento do homem natural foi gradativo e cedeu lugar a agrupamento de homens artificiais, de paixões fictícias. O homem selvagem conhece o repouso e, mais que tudo, a liberdade. O homem sob controle conhece o trabalho e a escravidão, só é feliz a partir do testemunho do outro e não mais apenas do seu próprio. Rousseau afirma que "Suas virtudes não passam de vícios disfarçados" (ROUSSEAU, 2000, p. 25).

Assumirmos a visão filosófica de Rousseau como parte do referencial teórico necessário à compreensão da questão da marginalidade nos parece fundamental, porém não suficiente. Ela nos sinaliza no sentido de que o Homem, em origem, não nasce mau. E esse é um posicionamento que precisa se tornar explícito em nossa análise. Entretanto, como bem ressaltamos anteriormente, o autor descarta, deliberadamente, os aspectos fisiológicos da natureza humana cuja importância crescente a ciência vem demonstrando, sobretudo a 
partir do início desse novo milênio. Passemos, assim, a encarar mais esta faceta que compõe a complexidade do tema.

O debate sobre o intrincado sistema que constitui a mente humana é objeto dos mais diferenciados posicionamentos. Entretanto, um aspecto se tornou consenso: nascemos antes do tempo. O fato de termos ficado em pé certamente foi fator crucial para o desenvolvimento de nossa inteligência e capacidade mental, mas determinou que o corpo das fêmeas pudessem suportar por menos tempo a gestação. Assim, diferentemente dos outros animais, deixamos o ventre materno sem que nossos circuitos cerebrais tenham chegado ao ponto ideal para o contato com a realidade do mundo aqui fora. Além do que, justamente em decorrência de nossa alargada capacidade para o conhecimento, passamos maior número de anos, entre a primeira infância e a adolescência, hibernando nossa sexualidade, diferente das outras espécies cuja transição é rápida e até necessária pois implica na questão da própria sobrevivência.

A evolução humana acabou por determinar a constituição de novas estruturas neurofisiológicas como, por exemplo, o neocórtex. Camada cerebral que passou a recobrir nossos centros neurológicos mais antigos e implicando em uma "especialização" de lobos cerebrais, um mais voltado para a racionalidade e outro para os instintos e a emocionalidade. ${ }^{12}$

O aspecto mais importante do impulso nervoso é a sua natureza química. A atividade química das diferentes regiões cerebrais resulta em comportamento. É justamente esse aspecto que nos interessa, na busca de uma orientação a respeito da natureza humana para o "bem" ou para o "mal". No que toca à marginalidade, esse pode ser um ponto decisivo, pois as estampagens primárias que possuímos - a serem consideradas quando da análise das questões antropológicas e culturais em nosso trabalho - levam a sociedade a associar o marginal a visões de crueldade, deformação ou irreversibilidade, o que pode ser patologia e não condição estrutural e necessária.

Vimos anteriormente que a atividade cerebral se dá em um nível cognitivo e em outro, emocional. As últimas descobertas científicas sinalizam que isso está relacionado à existência de cinco sistemas cerebrais, mencionados em Amen: Sistema Límbico Profundo,

\footnotetext{
12 AMEN, Daniel G. Transforme seu cérebro, transforme sua vida - Um programa revolucionário para vencer a ansiedade, depressão, obsessividade, raiva e impulsividade. São Paulo: Mercuryo, 2000.
} 
centro da formação de laços e controle de humores; Gânglios Basais - controlam a velocidade em "marcha-lenta" do corpo. Córtex Pré-Frontal -ajuda a concentração, fazer planos, tomar decisões. Cíngulo - permite a mudança de pensamento para pensamento e entre comportamentos; Lobos Temporais - Relacionados à memória, à linguagem e ao controle do temperamento.

Problemas de natureza química, de ordem genética, nutricional (fenômenos depressivos graves começam a ser associados à falta de ácidos graxos de cadeia curta ômega 3 - no organismo) ou adquirida, que ocorram nessas áreas cerebrais resultam em alterações de comportamento que modificam a capacidade de produção de conhecimento, do raciocínio e de emoções, resultando, muitas vezes, em atos que estão descritos em nosso sistema legal como crimes e que, de fato, comprometem a vida em sociedade. Entretanto, para mais além de encarceramento, estão a merecer tratamento e cuidado. Tais fatos são, no geral, completamente desconhecidos e justamente em razão da ignorância, estartam o medo e a fantasia, gerando mais exclusão e marginalidade. Fundam, em grande parte, crenças coletivas e justificam o aprofundamento das ferramentas discriminatórias, na base da construção da pobreza-política.

Relevante, portanto, que se incorpore ao universo da complexidade do debate sobre a marginalidade o fato de, biologicamente, estarmos ainda em um processo de desenvolvimento cerebral. Submetidos a fortes e constantes estímulos externos, provenientes da própria realidade da vida, ainda não podemos falar em um sistema acabado e pronto, apesar de muito já ter sido feito por esse excepcional instrumento adaptativo que é nosso cérebro, base fisiológica de nossas mentes. Maturama contribui, quando diz que o cérebro humano reconstrói, não só copia. Não retratamos, reconstruímos. Ao ordenar o discurso, ordenamos a própria realidade.

Outro aspecto ligado à marginalidade, como fenômeno decorrente da pobrezapolítica, aquela gestada na construção de enclausuramento humano - em que sentido for, literal ou não - guarda ligações com a área da biologia mas também com a antropologia e a psicologia. Trata-se do fenômeno das estampagens culturais. Procurando sermos mais claros, usaremos dois exemplos conhecidos: 1. todas as tartarugas, quando nascem, após romperem a barreira da areia onde seus ovos foram depositados, correm desesperadamente em direção ao mar; 2. Pintinhos, mesmo ainda muito novos, se abrigam sob as asas da 
galinha ao perceberem a sombra de um gavião (seja ela verdadeira ou criada pela mão humana, em experimentos sob controle). Campbel1 ${ }^{13}$, comentando os trabalhos de diferentes antropólogos, relativos a esses comportamentos característicos de espécies diferenciadas, mas também presente no registro de mitologias primitivas, ressalta que não podem ser decorrentes de aprendizado, e, sim, de um registro biológico, do tipo "chavefechadura", que trazemos ao mundo como conseqüência, isso sim, do aprendizado de nossos antepassados e incorporados à própria memória genética.

São de duas naturezas esses mecanismos. Há um sistema fechado, onde as estampagens foram tatuadas e não se transformam e um sistema aberto, que incorpora $o$ aprendizado da vida entre os iguais, da mesma espécie.

Sob a ótica da psicologia uma abordagem um pouco distinta, mas também acolhedora da força psíquica - que tem muito como base o processo químico de nossos cérebros - com que os registros se amoldam a nós, considera o inconsciente - individual, na visão de Freud e coletivo, na visão de Jung - a fonte de muitos de nossos comportamentos e na maioria das vezes, desconhecidos de nós mesmos.

Seja em razão de nossos registros biológicos, antropológicos ou psíquicos, o fato é que parece que há uma imagem mental associada à marginalidade e compartilhada socialmente. Originalmente ela pode ter se formado a partir da observação de fatos e comportamentos recorrentes de agressões sofridas ou presenciadas, mas certamente foi reforçada a partir do aparelho do Estado e de suas ações. Aspectos projetivos, hoje explicados por um grande número de correntes em psicologia, sobretudo a psicanálise, demonstram que a impossibilidade de suportarmos nosso lado sombrio, com freqüência determina a visualização, no outro, de nossos medos e conteúdos inconscientes. Mais claro, portanto, compreender a idéia da personificação do mau, do perigo e da ameaça, na figura do ladrão, do bandido, do assassino.

Foucault ${ }^{14}$, no âmbito da sociologia - último campo que chamamos para o debate do tema, sem, entretanto, acreditarmos que outras áreas do conhecimento não possam vir a enriquecer ainda mais a compreensão da complexidade do tema - iluminou as percepções a respeito do poder e da forma como o Estado, único detentor legítimo do mesmo, constrói

\footnotetext{
${ }^{13}$ CAMPBELL, Joseph. As Máscaras de Deus-Mitologia Primitiva, vol. I, 7ed., São Paulo: Palas Athena, 2005.

${ }^{14}$ FOUCAULT, Michel. Vigiar e Punir- História da Violência nas Prisões. Petrópolis: Vozes, 1977.
} 
sua teia invasiva e escravizante. Em suas obras, em especial em Vigiar e Punir e Microfísica do Poder, introduz a idéia do poder como algo não linear, dotado de uma dinâmica difusa, complexa. Ele é micro, habita as frestas, as entrelinhas, é manhoso e aparece já na base. Afirma que o conhecimento é uma das grandes fontes de poder, que as palavras interpretam as coisas, as reconstroem e isso é uma intermediação sempre controlada pelo poder, como comentamos anteriormente, a respeito de Maturama.

O poder, portanto, não precisa ser sangrento. Pode se expressar, e geralmente o faz, por artimanhas, redes de influência - divergindo da idéia de Habermas de que pode haver e que só há boa comunicação, quando essa não contiver poder.

Foucault, portanto, expõe a politicidade de todas as relações humanas, inclusive aquelas relativas às Políticas Sociais. E esse aspecto é de fundamental importância quando se pensa no tema da marginalidade. Faz com que retomemos nosso ponto de partida: o homem é mau por natureza e, assim, a marginalidade é característica de alguns - ou muitos de nós - ou, na realidade, a marginalidade é conseqüência de processos externos ao homem, fruto de uma sociedade disciplinar, de alterações biológicas, de manipulações da ignorância do homem a respeito de si próprio e patologias ou construções sociais?

Tendemos a nos alinhar com a percepção de Foucault de que todas as instituições enquadram, dizem o que vale e o que não vale em sociedade e até no nível individual. Elas constroem normas, sanções e cobram determinado tipo de comportamento. E aqueles que não se enquadrarem, serão considerados desviantes, marginais. A sociedade produz o medíocre e teme o diferente. Aprecia a rotina e a subserviência e parece não só não admitir como também não saber lidar com o que nela não se encaixa.

Assim, utiliza a ideologia como forma de manter no poder os que ali estão. Ele até gostaria de manter a imagem de que reina soberano, mas não é assim. E não é, porque há que se considerar que aqueles que "estão em baixo" possuem, também, possibilidade de alguma resposta. Têm menos poder, mas não deixam de tê-lo. No caso das penitenciárias, por exemplo, locus da agregação institucional da marginalidade, as rebeliões costumam retratar a força dos excluídos, ainda que de forma sangrenta.

Retomando, pois, a proposta dessa segunda etapa, que é a de contextualizar sóciohistoricamente a marginalidade de forma a melhor compreender o fenômeno, retomamos os 
pontos centrais levantados, para que nos sirvam de auxílio na próxima etapa de nosso trabalho, voltado à análise da realidade:

1. o trabalho de Rousseau, a respeito da origem das desigualdades entre os homens, nos leva a considerar, como premissa filosófica desse trabalho, que o Homem não é, por nascimento, mau;

2. que questões biológicas e nutricionais, de natureza química, envolvendo nossa neurofisiologia cerebral, interferem não apenas em nosso comportamento como na própria percepção e construção da realidade;

3. que estampagens culturais, abertas ou fechadas, herdadas ou desenvolvidas, influem fortemente em nossas crenças e mitos a respeito da marginalidade;

4. que nosso funcionamento psíquico é estruturado muito mais a partir de processos inconscientes do que conscientes, tornando cada um de nós potencialmente abertos a processos de marginalidade;

5. que a marginalidade é uma construção decorrente do processo de socialização, oriunda da assimetria de poder e do estabelecimento das regras de conduta e moral, que encobrem ideologias e se impõem através de mecanismos sinuosos e dissimulados, em um processo dinâmico, complexo e não linear.

Entramos, agora, na última etapa do trabalho que nos propusemos realizar, introduzindo a visão da realidade, do concreto, através da análise do trabalho desenvolvido, no Centro de Progressão Penitenciária de Brasília. Espaço institucional, destinado a funcionar como transição, para aqueles que, sendo marginais - em razão do descumprimento dos limites da margem, criados pela lei - saem de um regime de reclusão para o sistema semi-aberto, ou seja, passam a residir no local designado como "galpão"- situado no Setor de Indústria, em Brasilia - podendo sair durante o dia para trabalhar, retornando para dormir e, a cada quinze dias, obtendo autorização de visitar suas famílias, até que, de fato, voltem a obter a liberdade. 


\section{Centro de Progressão Penitenciária do Distrito Federal}

O relato transcrito, a seguir, é resultado do trabalho de atendimento psicológico aos internos, realizado no local, ao longo do segundo semestre de 2004.

\section{“A ilha do galpão"}

"Dura vinte e cinco minutos o trajeto entre o centro da cidade e o galpão, localizado no setor de indústria, que abriga 350 homens. Em sua maioria pardos, jovens e com escolaridade média de primeiro grau, têm em comum o fato de encontrarem-se sob o controle do poder Judiciário.

Todos são maiores de dezoito anos, embora a maioria não tenha ainda atingido os 30 anos. Tendo cometido crimes diversos, cumprem pena no regime semi-aberto. Isso significa que muitos já passaram pela reclusão - na Papuda - e agora desfrutam da evolução da pena.

Vivem em três alas distintas, situadas em um quadrado de tijolo à vista, onde há poucas janelas e dois pisos. A primeira ala, térrea, se destina a ex-soldados que tenham praticado algum ato lesivo aos artigos legais. As outras duas Alas, também no térreo, são na verdade grandes galpões, que abrigam cerca de 300 homens. Há beliches encostados uns nos outros para atender à necessidade de dormitório com um banheiro comunitário em cada uma das alas. De propriedade eles só têm um cobertor muito simples, cinzento e surrado, e a toalha de banho.

No segundo andar, um salão com piso de cimento e telhas de zinco improvisa quatro grandes salas de estudo e uma pequena biblioteca formada por doações privadas. Não chegam a ter 200 volumes de títulos que, em sua maioria, envolvem livros de matemática, português, história, geografia e física em nível de primeiro e segundo graus.

Viver ali significa um passo além do ostracismo. Podem sair para trabalhar, caso consigam alguma colocação. O retorno diário ao galpão é obrigatório. A cada quinze dias 
podem visitar a família no final de semana. Entretanto, qualquer falha de disciplina é punida de forma rigorosa sendo um dos castigos possíveis a suspensão do direito de visita às suas casas.

Há um pátio lateral onde são feitas, diariamente, quatro conferências por nome e onde um banho de sol é permitido, pela manhã. Nos fundos do prédio uma pequena horta, cuidada pelos internos, fornece legumes para o preparo da comida na cantina, pequena e precária.

Duas assistentes sociais trabalham em regime integral no atendimento das mais diversas necessidades. Há também uma sala reservada ao serviço jurídico que se encarrega de cumprir as ordens judiciais e um centro de disciplina. Há forte controle do movimento dos internos que, no geral, andam com as mãos para trás e são cobrados em relação à limpeza pessoal e vestuário. O lugar é bastante simples, mas muito limpo.

É entre as carteiras para aula, situadas no segundo pavimento, que se improvisa o atendimento psicológico voluntário, feito todas as sextas-feiras à tarde. A opção foi feita pela terapia individual. Espaço de escuta para a dor e o sofrimento individual daqueles que as assistentes sociais selecionaram como casos emergenciais.

As queixas são as mais diversas, embora o padrão de ansiedade seja absoluto. Alguns não dormem. Imagens violentas do regime fechado, somadas às preocupações com a família, que, quando é visitada, mostra sua cara de fome e abandono, habita os sonhos e a consciência de todos eles.

Trabalhar e estudar contribuem para a redução da pena, na forma da lei. Entretanto é um privilégio de poucos e objeto do desejo da maioria dos internos. O pouco que ganham levam para as companheiras e os filhos. Outros aceitam trabalhos voluntários, sem remuneração, para ajudar a passar um tempo que é distinto do que marca o relógio. Os dias tornam-se quase infinitos e muitos, muitos deles têm dores de cabeça crônica, crises de ansiedade e agitação evidente.

Dos relatos das visões de violência cravadas mais na alma do que na mente, está o "cubículo". Trata-se da parte de trás dos carros policiais (camburões) onde andam algemados, por vezes em grande velocidade, expostos a desastres e fantasias como "cair da ponte e não poder se salvar". 
Os rostos e corpos têm outras marcas. Orelhas quebradas, cicatrizes nos braços, boca, pescoço. Muitas delas foram feitas na infância, por mães iradas que arremessavam ferros de passar sobre as crianças ou em espancamentos familiares resultado do uso de drogas, de álcool, da infelicidade, da fome. "A vida bate nos pais, os pais batem nos filhos". As marcas bem profundas foram feitas no espancamento materno, durante a gestação. $O$ amor pela mãe e a ira contra o pai são quase uma unanimidade. $O$ abandono parece ser pré-requisito na vida de cada um deles. Muitos se criaram sozinhos nas ruas desde antes de cinco anos. Viviam em grupos, com algum irmão ou simplesmente perambulando à busca de um local para dormir e, quem sabe, até comer.

Um deles narra que após ter sido deixado, pela mãe, junto com mais dois irmãos, em um abrigo ou creche qualquer, nunca mais a viram. Sua crença é a de que ela não deu conta de suportar suas travessuras e o trabalho que davam. Não the ocorre que ela tomava remédios controlados e que podia ser portadora de uma patologia profunda. Para ele, a culpa se instalou na infância. Logo cedo o irmão ensinou que ele não podia deixar que qualquer um lhe batesse ou fizesse mal. Não importa que tivesse menos de dez anos. Era a lei da rua e ela a levou a um histórico de violência. Única forma vislumbrada de sobreviver não apenas entre aqueles que com ele partilhava as marquises e a fome, mas também nas delegacias, centros de reabilitação e mais tarde nos presídios. Reincidente, várias vezes, as cicatrizes por toda a cabeça e corpo fazem pensar se o melhor diagnóstico é uma periculosidade inexistente ou uma patologia desenvolvida em razão de danos fisiológicos. Solicitado exame médico, as assistentes sociais afirmam que não adianta muito pois "os médicos atendem os presidiários com medo e mal".

É comum que na família dos internos atendidos muitos tenham irmãos mortos ou cumprindo pena. A entrada no mundo da criminalidade forma, como afirmam eles, uma impossibilidade de volta. As gangues, vinganças, ódios, fazem com que não consigam reverter situações. Alguns alegam que ao sair do presídio podem ser mortos e mesmo dentro deles a proximidade com policiais ou uma conduta que exclua os companheiros de cárcere leva à interpretação de traição. Há linhas claramente desenhadas. Fronteiras invisíveis mas temíveis e terríveis. Invadi-las significa, em qualquer sentido, uma quase impossibilidade de retorno. 
Mágoa. Rancor. Dor física e/ou psíquica. Pensamentos obsessivos. Crises de pânico. Ansiedade. É o cotidiano de todos eles. Perguntados sobre "no que são bons" um silêncio pesado se faz. Ouvidos, se emocionam, choram. Trazem fotos dos filhos. Sorriem com a lembrança das mulheres que os esperam lá fora.

Aguardam com sofreguidão notícias do andamento de seus processos. A maioria deles não tem ninguém que acompanhe os intricados trâmites da Justiça. Algumas mães, se desdobrando entre o trabalho e a casa, economizam tostões para a passagem de ônibus até o Fórum. Lá, esperam horas na Vara de Execuções Criminais para qualquer notícia. Falam com freqüência na possibilidade de conseguirem a prisão domiciliar, a comutação da pena, a remissão, algum benefício ou simplesmente a contagem correta dos dias trabalhados para que possam desfrutar dos diretos que a lei lhes faculta.

Sempre comparecem ao atendimento psicológico de banho tomado, perfumados, bem penteados. Entre a tristeza de suas próprias histórias, intercalam risadas curtas e tímidas. Um escreve um livro. Outro é artista. Um terceiro guarda uma expressão facial deformada pelo abandono materno aos dois anos de idade. Adoeceu uma semana depois e o corpo registrou de forma indelével a impossibilidade de um grito de pavor. A avó paterna criou. O pai levou para as drogas, das quais ainda não conseguiu sair e onde o filho resistiu fortemente após anos de descaminho.

Mais um chega mancando, apoiado em uma pequena muleta, carregando uma garrafa de refrigerante com água que vai despejando sobre a perna esquerda, marcada por um tiro que lhe estraçalhou o nervo ciático e rende uma dor crônica lancinante. Espera a cirurgia que, necessariamente, irá tirar a sensibilidade da perna inteira e, se tudo der certo, também a dor. É ele que narra o sonho em que "estava em casa, e o irmâo tinha uns passarinhos presos em uma gaiola. Pensa em soltar os bichinhos, mas sente medo do irmão. Outro passarinho chega, e ele o liberta. Ele alimenta o pássaro. Abre-se a janela e ele voa". Nas palavras dele diz: "Rapaz, você não sabe o que é estar preso". Na semana seguinte, quando novo atendimento está agendado, não está mais lá. Recebeu a liberdade provisória... Cheio de dor. Mas livre!

Todos se emocionam quando tiram a carteira de identidade. Mais que um símbolo, ela exerce impacto importante sobre o senso de identidade e amplia a auto-estima. A maioria não gosta ou não consegue estudar. Alguns claramente têm problemas 
oftalmológicos. Outros pensam tanto, o dia todo, que não acessam um mínimo de paz interna que possibilite a leitura ou a compreensão. Sonho mesmo, a LIBERDADE!

Quase nunca falam sobre o delito cometido. Apenas vez ou outra. Referem-se aos demais como "ladrões". A pena é "puxada", em todos os seus anos. "Potocar" é jogar conversa fora com os outros. "Zoar" significa andar pelas ruas, fazendo farra. No presídio não se dança “que isso não é coisa de homem”. Há um dialeto interno.

Têm medo dos psicólogos. Perguntam se o que falam irá chegar ao Juiz. É que o único encontro que tiveram com essa área foi "um desenho que a gente faz e aí fica preso mais tempo". Mas as lembranças ruins não são só do pai, do psicólogo, do Juiz. “ $A$ professora torcia a orelha", "o pau-de-arara", "afogamento", "pancada”. "Na prisão, lá na Papuda, a gente desce pro pátio e não sabe se vai conseguir voltar. Uns já descem prontos pra matar". "No presídio sentiu que chegava ao fundo do poço".

Quando começam a se abrir perguntam: "porque a senhora vem aqui? deixa seu marido, seus filhos, pra falar com a gente?" Estranham e desconfiam de qualquer ação estranha à violência. Entretanto, vão cedendo à necessidade de escuta e se humanizam de uma forma tão profunda que surpreende a eles mesmos. E a quem ouve...Ensinam sobre "uma outra vida". A vida dos marginais, dos desviantes, dos excluídos. Falam de sonhos que foram cortados ainda na infância. Se é que se constituíram. Contam sobre um mundo que quem ouve nunca conheceu. Chocam ao escancarar uma realidade "irreal" para a população que vive há apenas vinte e cinco minutos dali. Não conhecem teóricos nem acadêmicos. Os bancos da escola muitas vezes foram o início do desvio, do vício, do crime. Alguns se evangelizam e buscam a regeneração dentro da própria unidade prisional. Ali há poucos professores. Um de matemática. Outro de português, que apareceu faz pouco. Dão aulas à noite. Na ilha do ostracismo quase ninguém se dispõe a aparecer. São tratados muitas vezes de forma humilhante, degradante, desumana. Embora alguns dos que trabalhem lá demonstrem fortemente as qualidades necessárias para o propósito a que deve servir a pena: re-socializar.

No final da tarde, ao transpor o portão entre a "ilha do galpão" e o mundo da cidade, os minutos até o centro são sempre de profundo silêncio e questionamento. Nunca se sai de lá sem um novo aprendizado. Eles, os mestres da exclusão, reviram pelo avesso os conceitos acadêmicos, as crenças, a visão interna. Desafiam nossas mentes, nosso 
propósito, nossos objetivos. Exigem de forma silenciosa o uso concreto do conhecimento em prol da ética cidadã. Não pedem discurso. Exigem ação. Solução. Mudança. Evolução.”

A legislação penal brasileira alega ter como base, em relação àqueles que descumprem a lei, que extrapolam a margem, aos marginais, um objetivo básico: a resocialização. Um dos instrumentos que sustenta ter criado com essa finalidade é justamente a adoção de um regime chamado de semi-aberto. Destinado a internos que cometeram crimes de menor gravidade ou que, ao saírem do regime de reclusão, onde a liberdade é totalmente vedada, passam por um período de transição, permanecendo em uma instituição à noite, podendo sair para trabalharem e a cada quinzena, visitando a família. Esse é exatamente o caso do Centro de Progressão Penitenciária do Distrito Federal.

Analisando essa proposta, "de dentro", ou seja, a partir da vivência da vida diária do trabalho ali desenvolvido, o que se pode concluir é que o discurso e a prática encontram-se grandemente dissociados, senão, vejamos:

1. É verdade que, geograficamente, o prédio do CPP-DF encontra-se mais próximo à vida da sociedade brasiliense. Diferentemente da Papuda, que por questões de segurança, foi construída a muitos quilômetros do Plano Piloto, esse estabelecimento prisional partilha da rotina do Setor de Indústrias, estando mais ligado a um ambiente de trabalho, mas não de residência nem dos internos, nem da população em geral;

2. Embora a lei seja para todos, a ampla maioria dos internos do CPP-DF é de negros, pardos e pobres, com escolaridade média de primeiro grau e com quase nenhum apoio em termos de educação e saúde;

3. A faixa etária predominante é de 18 a 25 anos - coincidindo com estudos que relacionam esse período como o mais crítico em relação ao cumprimento de regras, pois representa a saída da adolescência e o desafio de entrada em um mercado de trabalho que, sabemos, premia os bem formados e exclui os que para ele não estejam preparados. Relacionando-se com a observação do item anterior, parece que apenas negros, pardos e pobres, com baixa escolaridade, integram o contingente dos rejeitados socialmente; 
4. É fato que podem sair para trabalhar. Entretanto, encontrar emprego é exceção. É mesmo de se questionar se, caso tivessem conseguido o trabalho anteriormente, teriam chegado a se marginalizar. Isso expõem a primeira grande dissociação entre o discurso e a prática, pois não recebem formação para qualquer tipo de trabalho, nem educação e ainda encontram pela frente o preconceito dos empregadores, pois, conforme comentado, as estampagens sobre a marginalidade fazem parte de nosso inconsciente;

5. A visita à família é uma possibilidade, mas não uma garantia. No CPP-DF, quando a rígida disciplina - que envolve três chamadas por dia para conferência dos internos - é desrespeitada, toda a ala do interno indisciplinado é punida com a suspensão dessa prerrogativa, tendo ou não, a maioria deles, sequer tomado conhecimento do que ocorreu;

6. A comida é fornecida através de "quentinhas"- marmitas - adquiridas pelo governo do Distrito Federal. Entretanto, criam-se regras internas e paralelas, para tudo e qualquer incremento na refeição, como um ovo, um sistema de trocas se estabelece. Obviamente, aqueles que possuem mais dinheiros ou bens de qualquer espécie, melhor a situação, repetindo o padrão social da mesma sociedade que os excluiu;

7. Dentro do pavilhão do CPP, denominado pelos internos de "galpão", os internos devem andar sempre de mãos para trás, abaixar a cabeça diante dos guardas e superiores e mostrar um comportamento submisso e calmo. As revistas envolvem procedimentos por vezes degradantes onde os guardas usam luvas e realizam o procedimento de cada interno, dividido dos demais por um biombo;

8. É verdade que o serviço de assistência social se desdobra na tentativa de atender bem os internos, assim como a área de apoio jurídico, entretanto, o quadro desses funcionários é tão pequeno que mesmo os maiores esforços e as melhores intenções são poucos, diante do número e volume das demandas;

9. Isso implica que inúmeros internos passem mais tempo presos do que deveriam. Se por eles mesmos não tiverem quem busque lutar pelos seus direitos, nada há a ser feito; 
10. Não há serviço médico. Doenças, das pequenas, às graves, precisam aguardar vagas no atendimento público e, muitas vezes, essa é uma questão que se mostra fatal;

11. Ninguém vai ao CPP. É bem provável que a imensa maioria da população sequer tenha conhecimento da sua existência. É a ilha do ostracismo. Para mais além do desinteresse da população pelos marginais, há a mentalidade de que talvez devam mesmo "sofrer muito" e nunca mais voltar;

12. Talvez isso seja a causa da surpresa que manifestam quando, por iniciativa própria, qualquer voluntário resolva desenvolver algum trabalho com eles. Também é verdade que isso nunca dura muito e que no contato direto seja flagrante o "medo" de que uma situação extraordinária aconteça - uma rebelião, por exemplo;

13. O tempo dos internos, dentro do CPP, é um tempo lento e espichado. Os minutos viram horas e o tédio, somado à ansiedade, falta de comunicação com a família e os sentimentos de depressão e angústia tornam desesperadora a espera da liberdade. Se a proposta fosse mesmo de re-socialização, esse tempo seria útil para a formação de habilidades profissionais ou à educação. Mas não é o que ocorre;

14. A postura dos policiais no $\mathrm{CPP}$, sem dúvida, é menos rígida do que em estabelecimentos prisionais de reclusão, onde, para além da desumanidade o que prevalece é a crueldade e impunidade. Mas a observação "por dentro" da vida de qualquer instituição nessa área escancara relações de poder e elas também se estendem entre os próprios internos, onde uns são mais poderosos que os outros;

15. Também fica claro - e não apenas para quem tem formação específica na área da saúde - que os problemas psíquicos e neurofisiológicos dos internos são quantitativamente importantes. Estudos sinalizam, e lá se pode observar, que a dislexia pode ter sido a causa da entrada na marginalidade, de muitos deles. Que lesões causadas pelos pais, amigos, polícia ou em confrontos entre gangues ou lutas de rua, certamente deixaram mais do que lembranças e se transformaram em patologias. Que não há como manter a integridade química de um cérebro submetido a uma nutrição precária e rotineira, a processos depressivos de ampla 
profundidade e a uma humilhação da qual não há como se livrar - culpado ou inocente;

16. As habilidades de cada um desses seres humanos que ali se encontram não são nem minimamente consideradas. Iniciativa e criatividade representam perigo. É proibido pensar. Imaginem ensinar a pensar!;

17. A questão da Carteira de Identidade chama a atenção. É um símbolo de autopercepção. Um reconhecimento de existência. Tirá-la, ainda que pouco represente para quem perdeu direitos, inclusive políticos, é uma vitória;

18. De tudo, o que mais surpreende é perceber a reação desses homens, quando se lhes abre espaço de escuta e atenção. De início, tímidos e receosos, vão aos poucos relaxando. Emocionam-se, humanizam-se, no sentido profundo dessa palavra, como se muito poucas vezes na vida tivessem tido essa oportunidade. É provável que não tenham tido mesmo;

\section{Conclusão}

O objetivo desse trabalho foi o de analisar a marginalidade como fenômeno decorrente da pobreza política. Pobreza essa decorrente não dos aspectos econômicos, quantitativos, mas sim dos qualitativos. Da pobreza que se origina das desigualdades sociais, das relações de poder e da supremacia de uns, a custo da desumanização e subserviência de outros, esses, ampla maioria.

Para tanto, discutimos a questão da marginalidade, propondo-nos um questionamento sobre ser ela originária ou construída. Buscamos na filosofia, em Rousseau, uma resposta. Ele sinalizou que, por natureza, o homem não é nem bom nem mau, até em razão de que esses conceitos, dependentes de valores, são construídos dentro da sociedade e não no próprio homem. Pontuou que foi exatamente na passagem do estado de natureza para a vida em sociedade, que o homem deixou de se ter como referencial de si próprio e, nessa encruzilhada, passou a trilhar o desvio cruel da perda da auto-estima e da autoreflexão.

Essas duas características, apontadas pelo filósofo, são, ainda hoje, a base da pobreza política e da profunda desigualdade entre os homens. Com o estabelecimento do 
controle de muitos, por poucos, estabeleceram-se as regras, as leis. Alegando serem elas necessárias à vida da sociedade, passaram a utilizá-las como instrumento de dominação. Construíram os limites entre os que estão fora e os que estão dentro. Inventaram a marginalidade.

O marginal, construído pela força da lei e dos preconceitos, tornou-se excelente objeto e repositório de nossos medos e estampagens inconscientes e passaram a "merecer" o ostracismo, o abandono, a exclusão definitiva do âmbito social.

As políticas sociais voltadas a esses homens recebem, como no caso do Distrito Federal, slogans do tipo: TOLERÂNCIA ZERO. Foram excluídos, não têm chance de reinclusão, e todos consideram isso absolutamente natural.

Os orientais dizem que a origem dos problemas da humanidade são: o medo; a ignorância e o apego. Todos esse três requisitos se somam na questão da marginalidade. Tememos o marginal, desconhecemos como ele se forma - e nossa responsabilidade nisso e ele representa, para nós, uma eterna ameaça. Não é por acaso que muitos pensam que "bandido bom é bandido morto".

Não se trata de fazermos uma apologia ao marginal ou desconhecer que há níveis de periculosidade neles. Mas não há em nós? Por acaso nossos políticos - elaboradores das leis construtoras da margem - não devem provocar preocupações de igual natureza? Mas a elite parece estar acima da lei.

O grave dessa situação é que, mesmo as políticas sociais constituídas para eles, sequer utilizam o disfarce do assistencialismo das demais. E estando sob vigilância constante do Estado, a única forma de auto-organização possível costuma ocorrer em sangrentos embates, como foram as rebeliões de diversos presídios.

Parece que urge a adoção de medidas concretas que reduzam a pobreza política desses indivíduos, em virtude da qual a marginalidade não apenas chega, como se instala, em caráter definitivo. Uma delas passa, certamente, por curar a esquizofrenia do discurso "reintegração social" e prática desumanizante. É fato que a verdadeira saída é a que se dá pela via da auto-organização, mas nesse caso, como viabilizá-la?

Parece importante colocar o conhecimento de que dispomos à disposição de construções de alternativas. Uma delas a iniciativa de desvendar as estampagens e preconceitos dos que elaboram a lei e constroem a marginalidade, por acreditarmos que a 
redução da pobreza política passa, em boa medida, pelo conhecimento dos subterrâneos da mente humana e suas intrincadas construções para a justificativa do poder e lida com a própria ignorância.

Políticas Sociais de boa qualidade devem mesmo primar por serem construídas "de baixo para cima", viabilizarem-se por si mesmas e englobarem lideranças legítimas, mas, no âmbito dos estabelecimentos prisionais, esse é um desafio a merecer maior aprofundamento, em razão de suas características específicas e dos conteúdos emocionais relacionados à marginalidade. É surpreendente como, mesmo entre os marginais, a consciência dos fatores que os remeteram a essa situação é praticamente ignorada, caracterizando a forma mais verdadeira de dominação e a verdadeira pobreza política: aquela em que o dominado desconhece sua condição.

\section{Bibliografia}

AMEN, Daniel G. Transforme seu cérebro, transforme sua vida - Um programa revolucionário para vencer a ansiedade, depressão, obsessividade, raiva e impulsividade. São Paulo: Mercuryo, 2000.

BATISTA, Vera. “A Construção do Transgressor" p. 157-163.

CAMPBELL, Joseph. As Máscaras de Deus - Mitologia Primitiva, vol I, 7ed., São Paulo: Palas Athena, 2005.

CASTEL, R. (1998). "Os Marginais na História" in SER SOCIAL - Exclusão Social e Situações de Risco", Revista do Programa de Pós-Graduação em Política Social do Departamento de Serviço Social da Universidade de Brasília, Número 3, julho a dezembro de 1998. p. 55-67.

COIMBRA, Cecília "Produzindo o Mito da 'guerra civil': naturalizando a violência", p. 165-173.

DEMO, Pedro. Pobreza Política (Pobreza Humana). site: http://pedrodemo.sites.uol.com.br . Pobreza Política.Campinas: Editora Autores Associados, 1996.

Exchusão Social - categorias novas para velhas realidades in SER SOCIAL -

"Exclusão Social e Situações de Risco", Revista do Programa de Pós-Graduação em Política Social do Departamento de Serviço Social da Universidade de Brasília, Número 3, julho a dezembro de 1998. p. $12-55$.

. Solidariedade como efeito de poder. São Paulo: Cortez, 2002.

Pobreza da Pobreza. Petrópolis: Editora Vozes, 2003. 
FOUCAULT, Michel. Vigiar e Punir - História da Violência nas Prisões. Petrópolis: Vozes, 1977. . Os Anormais. Martins Fontes: São Paulo - Curso no Collège de France, 2001.

ROUSSEAU, Jean-Jacques. Discurso sobre a Origem e os Fundamentos da Desigualdade entre os Homens. In Coleção Os Pensadores, Rousseau, vol. II, São Paulo: Editora Nova Cultural, 2000.

SAWAIA, Bader. Org. As Artimanhas da Exclusão. 4.ed. Rio de Janeiro: Vozes.

SOUZA, Meriti. “A Experiência Transgressiva: leis e adolescentes". In Pulsional Revista de Psicanálise, ano XIV, n. 147, 52-65. 